\title{
Institutional and Partisan Sources of Legislative Conflict: The Brazilian Case
}

\author{
Taeko Hiroi | The University of Texas at El Paso \\ Lucio Rennó | Universidade de Brasília
}

\begin{abstract}
We assess the effects of individual, partisan, and institutional dimensions of conflict on the duration and outcome of the legislative processes in the Brazilian Congress. Our analysis indicates that legislative approval is more likely when the size of the governing coalition is either relatively small or extremely large and least likely when the coalition size is barely over the supermajority threshold to approve constitutional amendments. In contrast, legislative rejection is less likely with either modestly sized coalitions or very large coalitions, but most likely when it is approximately the size of the supermajority threshold. We also find that the effects of certain institutional variables are time-variant. Bicameral incongruence initially has a positive effect on legislative approval but soon begins to yield negative effects, delaying bills' passage. On the other hand, with the passage of time, executive proposals are less likely to be approved or rejected, although their initial effects are the opposite. Finally, preference heterogeneity among Brazilian deputies, which should have a significant impact if lawmaking were contingent upon individualistic politicians and weak parties unable to deliver bloc votes, has mixed effects: it has no statistically discernible impact on legislative passage. However, it has a delaying effect on proposal rejection.
\end{abstract}

\section{Introduction}

Many theories of lawmaking and gridlock in presidential systems have been proposed. Most extant work today centers on the effect of government-opposition conflict, as exemplified by the theory of divided government (Fiorina 1996; Mayhew 1991). Besides divided government, scholars have proposed ideological and institutional factors as causes of gridlock (Krehbiel 1996; Binder 1999, 2003). However, most of these explanations have not been extensively tested outside of the United States, and as such, we do not know whether and to what degree these explanations hold in non-U.S. presidential systems, such as in Latin America, where basic assumptions may be different. Many Latin American countries feature presidential systems with executives with strong agenda-setting powers, many and inchoate political parties, and legislatures with relatively high turnovers, resulting in many of their occupants being amateur legislators or legislators with progressive, rather than static, ambitions. These are aspects quite different from the U.S. system, and thus U.S.-based theories may need adjustments and their research findings may not be replicated in Latin America.

Are the theories based on government-opposition rivalries relevant in places where multiple parties exist and party discipline cannot be taken for granted? Or are explanations stressing individual legislators and their preferences more relevant in such systems? How about other dimensions of legislative conflict? Other prior research has emphasized institutional causes of legislative stalemate, such as bicameral differences (Tsebelis and Money 1997; Binder 1999, 2003) and supermajority rules (Krebhiel 1996). Is bicameral conflict pertinent in a system where executives tend to dominate legislative processes (Figueiredo and Limongi 2001)? Do supermajority rules generate a greater propensity for gridlock even in places where presidents are armed with many legislative prerogatives not available to U.S. presidents? We seek to answer these questions.

In this paper, we examine the effects of individual, partisan, and institutional dimensions of 
legislative conflict on the duration and outcome of the legislative processes in the Brazilian Congress. Our analysis of 1,597 legislative proposals presented to and considered by the Brazilian Congress between 1995 and 2004 indicates that government-opposition rivalry and institutional conflicts significantly influence the timing of legislative approval and rejection. In particular, our analysis reveals that legislative approval is more likely when the size of the government coalition is either relatively small or extremely large and least likely when the coalition size is barely over the supermajority threshold (60 percent) to approve constitutional amendments. In contrast, legislative rejection is less likely with either modestly sized coalitions or very large coalitions, but most likely when it is approximately the size of the supermajority threshold. We also find that the effects of certain institutional variables are time-variant. Bicameral incongruence initially has a positive effect on legislative approval but soon begins to yield negative effects, delaying bills' passage. On the other hand, with the passage of time, executive proposals are less likely to be approved or rejected, although their initial effects are the opposite. Proposals requiring supermajority votes experience slow legislative deliberation initially, but they are more likely to be approved as time passes. Finally, preference heterogeneity among Brazilian deputies, which should have a significant impact if lawmaking were contingent upon individualistic politicians and weak parties unable to deliver bloc votes, has mixed effects: it has no statistically discernible impact on legislative passage. However, it has a delaying effect on proposal rejection.

In the next two sections we discuss various explanations for legislative gridlock in the United States and Brazil. We then describe our main variables and dataset. Finally, we test the hypotheses using data on policy-making inside the Brazilian Congress.

\section{Institutional and Partisan Sources of Legislative Conflict in the United States}

Divided government is a situation in which different parties control the legislative and executive branches. When this occurs, the propensity for stalemate in the decision-making process is potentially higher, or so it was thought before David Mayhew's seminal 1991 study. Mayhew challenged the then conventional wisdom and argued that the United States political system is able to approve legislative proposals even under divided government. By studying the absolute number of important legislative proposals approved in periods of divided and unified government, Mayhew found that highly visible and relevant legislative proposals, prone to more controversy and dissent, passed under moments of divided as well as unified government. Furthermore, divided government did not particularly stimulate high-publicity investigations by Congress. In sum, productivity by Congress, especially in the enact- ment of significant legislation, is indifferent to divided government.

Mayhew's work inspired much of the subsequent research on legislative success and gridlock in American politics, both supporting and refuting the alleged effects of divided government (see Fiorina 1996 for an excellent summary). For example, Krehbiel $(1996,1998)$ argues that gridlock is a product of supermajority legislative procedures, such as a two-thirds veto override majority and a three-fifths cloture provision on the filibuster, and preference heterogeneity rather than an attribute of divided government. Krehbiel's empirical analyses of legislative productivity show that the position of the status quo ante and the positions of pivotal legislators given the supermajority rules determine legislative movement but that divided or unified control of government makes little difference. In fact, Krehbiel contends that unified government should not qualitatively differ from divided government in the absence of strong parties that alter the voting behavior of legislators who form a majority party in Congress. This point resonates well in Brazil, which not only lacks a clear majority party but also features parties notorious for incoherence and weak discipline (Ames 2001; Mainwaring 1999).

Binder $(1999,2003)$ also takes issue with Mayhew's and others' measurement of gridlock. Binder correctly points out that "gridlock is not the inverse of legislative output" $(1999,520)$. Low numbers of enacted laws may reflect a small legislative agenda, or could indicate the political system's inability to pass legislation despite a large legislative agenda. Therefore, it is imperative to take into account the size of the legislative agenda that Congress faces in order to test how effective it is in delivering legislation. The measure of gridlock the author uses is a ratio of approved important legislation to the size of the legislative agenda based on the issues that appear in the editorials of the New York Times. Using this dependent variable, she tests competing explanations for legislative gridlock. Her statistical analysis shows that divided government does have a modest impact on gridlock. However, she finds that other institutional, partisan, and preference variables, such as bicameral distance, party polarization, and preference diversity, have stronger explanatory power. Thus, Binder's study indicates that the structure of preferences across parties and across legislative chambers is central to explaining gridlock, even more so than inter-branch conflict.

Nonetheless, the impact of bicameralism on legislative productivity has also been challenged. Rogers claims that if both chambers of Congress can originate and terminate legislation, "cameral choice will have an indeterminate effect on legislative production" $(2003,509)$. The logic is that if the second chamber only had veto power over law production, then it would be a serious hurdle to legislative productivity. However, if second chambers are also law proposers and innovators, they may contribute to 
legislative productivity. If this is the case, bicameralism should have no impact on gridlock because of its initiating powers conjugated with terminative ones. In sum, gridlock depends on the productivity of the two chambers, not just on its hurdle-creating properties. Therefore, Rogers questions the conventional wisdom that two-chamber legislatures produce less legislation.

Finally, the research agenda on legislative productivity in the United States has also moved on to the analysis of legislative stability and how divided government affects the durability of enacted legislation. Maltzman and Shipan (2008) analyze the impact of inter-branch and intra-branch dissent at the time of enactment on the amendment of legislation thereafter. Maltzman and Shipan argue that political conditions at the time of enactment, divided government and disagreement between House and Senate in particular, influence the likelihood that a law will be amended. Furthermore, the probability of a law being amended also depends upon future political conditions. The authors demonstrate in their study of the U.S. Congress that in moments of divided government and bicameral differences, amending is less likely.

\section{Institutional and Partisan Sources of Legislative Conflict in a Multiparty Legislature and Coalitional Presidentialism}

This very influential agenda on divided government and other dimensions of legislative conflict in the study of U.S. politics has found little direct resonance in other separation of powers systems. The lack of comparable studies in Latin America may be due to the perception that divided government in the strict sense is "almost exclusively an American peculiarity" (Cheibub, Przeworski and Saiegh 2004, 573). However, outside the United States minority presidents that do not hold a legislative majority solely on their own partisan bases are ubiquitous. According to Cheibub, Przeworski and Saiegh (2004), about one half of cases under presidentialism between 1946 and 1999 experienced this situation, and government coalitions were formed in more than half of these cases, often generating coalitional rather than single-party majorities. These minority and coalitional governments are analogous to divided government in the United States (Laver and Shepsle 1991).

Thus, we are left with the intriguing questions about the impact of coalitions in the dynamics of gridlock. Do coalitions function as unified, homogenous bodies? Do coalitional divisions cause as much inter- and intra-branch conflict in legislative activity as that expected under a more classic divided government setting? How does the government-opposition divide influence a multiparty legislature's ability to pass bills?

Research on legislative gridlock is not new to students of Latin American politics. Scholars have argued that legislative gridlock and inter-branch conflict are responsible for the frequent breakdown of democracies in the region (Santos 1986; Linz 1978). Santos (1986), for instance, blames the increasing polarization between political parties and fragmentation inside the Chamber of Deputies for causing gridlock in Brazil, leading to a military coup in 1964. Linz (1978) points to the inability of presidential regimes to curb gridlock and solve crisis as a permanent source of political instability in the region.

More recently, the debate has also moved to the discussion of how electoral rules may engender legislative stalemate, by stimulating backbencher defections and pork-oriented legislatures (Ames 2001). According to this approach, especially that espoused by Ames (2001), electoral rules that personalize the vote and create the incentives for multiple political parties increase the number of veto players and impose severe restrictions for Congress to deliberate. Furthermore, many parties are unable to assure cooperation of their members in Congress because members tend to attribute their electoral fortunes to their own work rather than their parties'. Instead, cooperation is sought through selective incentives, of which pork and patronage are key factors. This leads to a Congress that becomes mostly pork-oriented rather than policy-oriented. If policies are ever enacted, they focus on the distribution of concentrated benefits with diffuse costs.

Obviously, this scenario fits the Brazilian case well, which is the focus of Ames' study, but it can also be applied to account for legislative patterns in Colombia (Botero and Renno 2007; Crisp and Desposato 2004) and potentially elsewhere. In some countries, the situation is even more dramatic, with systems prone to instability and to gridlock that lead to failed democracies, such as Ecuador and Bolivia (Mainwaring and Scully 1995; Perez-Liñan 2007; Llanos and Mainstentredet 2010) and to serious hindrances to how budgetary policy is defined, for instance, in Argentina (Hallerberg et al. 2009).

As these examples show, there is no shortage of research on gridlock in Latin America. However, rather than directly examining legislative productivity or gridlock, most of the extant work has chosen to analyze the factors that have implications for gridlock, such as patterns of roll calls and party discipline, the sponsors and scope of bills, and alleged consequences of gridlock, such as collapse of democracies. But policy-making itself, which is in the essence of the discussion about divided government and gridlock, has not been sufficiently addressed.

Divided government or a divided congress may cause gridlock for two reasons. For one, when there is no concurrent inter-branch and intra-branch majority, disagreements on a policy among political actors is likely to stall, or at least delay, the passage of new legislation. Second, the rivalry between government and opposition transforms legislative activity 
into a zero-sum game in which one side's gain is the other's loss, resulting in the mutual veto of legislation and hence a greater incidence of gridlock.

Measuring divided or unified government is not as straightforward in multiparty systems as in a two-party system. One way to evaluate the effect of government-opposition rivalry, which is the essence of divided government, in such a system is to examine the distribution of government and opposition forces within the legislature. We argue that the rivalry between the government and opposition forces becomes more intense as legislative seats are more evenly divided between them.

As discussed above, bitter partisan and coalition politics turn legislative approval into a zero-sum game, and when government and opposition forces approximate parity, a claim of victory by the government signifies an unacceptable loss for the opposition, and vice versa. Since many legislators believe that legislative outcomes have electoral consequences, they will be motivated to differentiate themselves and mark clear and distinct positions on important issues. Moreover, both sides know they are powerful enough to block legislation promoted by the other side. Consequently, neither side has an incentive to back down, complicating legislative bargaining. Under these environments, reaching agreement is difficult, making it less likely that bills will be approved. If bills are to be approved in these circumstances, delays are more likely as the two camps bargain hard over legislation. Conversely, there should be less conflict when either side clearly dominates the legislative institution.

We therefore expect a U-curve relationship between the timing of legislative approval within Congress and the division of legislative forces between the government and opposition. Legislative approval is more likely when the size of the government coalition is either small or large and less likely when the government and opposition relatively equally share legislative seats. We further expect that the relationship between legislative rejection and division of legislative seats takes a reserve- $U$ curve shape: rejection is less likely when the size of the government coalition is either small or large, but more likely when it is roughly equal to the size of the opposition.

Hypothesis 1a (The government-opposition divide in Congress): Legislative approval is more likely when the size of the government coalition is either small or large and less likely when the government and opposition relatively equally share legislative seats.

Hypothesis 16 (The government-opposition divide in Congress): Legislative rejection is less likely when the size of the government coalition is either small or large and more likely when the government and opposition relatively equally share legislative seats.

There is a caveat in the discussion above. Our hypotheses are based on an implicit assumption that coalitions are meaningful analytic units that have important consequences. Yet, such assumption can be challenged because, as discussed, many political parties in Latin America are relatively new, weak, and undisciplined. If parties cannot act as unified actors, one may rightly argue that size of coalitions will not be a useful predictor of legislative duration or outcomes.

In the United States, as discussed previously, many influential studies have found that divided government or government-opposition rivalry is not as detrimental to legislative productivity as often alleged. Many of these studies also offer alternative explanations for gridlock. One such alternative hypothesis is preference heterogeneity among legislative actors. For example, Krehbiel $(1996,1998)$ suggests that unified and divided governments should be qualitatively equivalent in the absence of strong parties that alter the voting behavior of legislators who form a majority party in Congress, a point that resonates importantly in Brazil and other Latin American countries where party discipline is weak. Instead, Krehbiel emphasizes the configuration of individual legislators' preferences, especially the preferences of pivotal legislative actors. Binder $(1999,2003)$ also finds that preference diversity in Congress increases the likelihood that gridlock will occur.

Preference heterogeneity in Congress may affect not only the outcomes of legislative effort but also its processes. In particular, since more diversified preferences mean, ceteris paribus, more difficulty in reaching consensus, we expect the effect of preference heterogeneity to be inaction or more bargaining, in short, delayed decisions, regardless of their outcomes. We therefore test the effect of preference heterogeneity on the duration and outcomes of legislation.

Hypothesis 2 (Preference heterogeneity): The greater the preference heterogeneity among the members of Congress, the more time will be spent in Congress without a final decision.

One of the most important institutional dimensions of legislative conflict in bicameral legislatures is inter-chamber conflict. Work by Tsebelis and Money (1997), Binder (1999, 2003), and Hiroi (2008) indicates that bicameral incongruence generates potential gridlock, as demonstrated by their research on France, U.S., and Brazil, respectively. However, as Rogers has pointed out, if both chambers have legislation-initiating powers and not just termination ones, bicameral incongruence may paradoxically lead to increase in overall legislative productivity instead of its decrease, even though the probability of any particular bill being approved by Congress may decline. We expect that bicameral incongruence will delay the legislative process and make approval of legislative proposals less likely.

Hypothesis 3 (Bicameral incongruence): The greater the incongruence between the upper and lower hou- 
ses of Congress, the longer it will take to approve legislative proposals.

Another alternative institutional hypothesis relates to the effect of supermajority voting rules, which is rarely examined in Latin American legislative studies, despite their frequent use in the region and in spite of their demonstrated gridlock-generating property in the U.S. Since approval of legislation under a qualified majority rule requires more yes votes than a simple majority rule, we expect that it will take more time to garner enough support for the legislation. Thus:

Hypothesis 4 (Voting rules): Qualified majority rules delay legislative approval compared to a simple majority rule.

One characteristic that differentiates many Latin American presidential systems from their U.S. counterpart is presidents' explicit and dominant legislative roles in the former. Unlike U.S. presidents, many Latin American presidents have extensive formal agenda-setting powers and are central actors in assuring the approval of policy proposals in Congress (Shugart and Carey 1992; Limongi and Figueiredo 1999; Cox and Morgenstern 2001; Tsebelis and Aleman 2005). With the use of extraordinary legislative prerogatives and leadership in constructing majority coalitions in Congress, Latin American presidents advance their policy agendas (Power 1998; Figueiredo and Limongi 1999; Amorim Neto and Tafner 2002; Reich 2002; Amorim Neto, Cox and McCubbins 2003; Negretto 2004; Pereira et al. 2005, 2008; Almeida and Santos 2008; Pachón 2008; Palanza 2009). Although the bargaining ability and legislative powers of the executive and legislative branches vary by country, the general pattern of executive initiative in policy-making tends to prevail (Cox and Morgenstern 2001). Hence, the prevalence of the executive branch in the policy-making process needs to be taken into account when analyzing legislative activities in Latin America.

Hypothesis 5 (Executive proposals): Executive proposals are more likely to be approved than bills proposed by members of Congress.

It is important to keep in mind that the executive dominance of the legislative process in Latin America does not mean that legislatures are simply rubber-stamp institutions, as they were during the military dictatorships and early days of democracy in the 1980s and 1990s (Close 1994). As Johnson and Crisp (2003) very accurately point out, legislators' preferences in Latin America do affect the ability of the executive branch to implement its agenda, forcing the government to negotiate with members of Congress on policy content and by distributing pork and other tangible and intangible benefits (Alston and Mueller 2005). It is also for this reason that the configuration of divided government and government-opposition conflict matter in the region: it is because legislatures have become key political actors and central arenas for decision-making.

\section{The Dependent Variable and Method}

We use event history analysis to test our hypotheses regarding individual, partisan, and institutional dimensions of conflict using data on individual bills submitted to the Brazilian Congress between 1995 and 2003. In practice, this period covers the two terms of President Fernando Henrique Cardoso (1995-1998; 1999-2002) and the initial year of President Luiz Inácio Lula da Silva's first term (20032006). Our dependent variable is the time to a final decision on legislative proposals as well as type of decision in Congress. As Ames (2001) points out, many bills that are proposed to Congress never reach a vote, and long delays are common for many others that are eventually voted up or down. Some important and controversial bills stay in Congress for many years, even decades. Therefore, we need to look at the time of a decision as well as the decision itself in order to accurately understand the dynamics of lawmaking.

We utilize legislative data compiled by Hiroi (2008) to track the fate of individual bills submitted during this period. The dataset consists of proposals for constitutional amendments and two types of statutory bills-ordinary and complementary (enabling laws). It includes all executive and judicial proposals. With respect to congressional proposals, the dataset includes all bills submitted and subsequently approved at least by the house of origin. ${ }^{1}$ We converted these data into monthly data and traced, in days, the histories of these bills from their introduction to Congress by assigning a series of Os for each observational period until their final decision-approval or rejection-at which time a value of 1 is assigned. Bills that were terminated for other reasons (e.g., withdrawal by the author, termination of deliberation at the end of a legislative period, etc.) are treated as "censored" at the time of the decision. ${ }^{2}$ In the case of pending bills, their histories are traced until July 31, 2004, on which date they "exit" the dataset. This cut-off date was determined by the availability of data in the dataset. However, the reader should be reminded that the information on all forms of bill termination as well as pending bills is used to estimate duration of legislative process in an event history analysis.

Event history analysis is an appropriate method to use when one's interest is in both the decision and speed of deliberation because we can consider not only whether proposals were approved or rejected but also how long it took for Congress to make that decision. We estimate our model using a semi-parametric Cox regression method. This method estimates the effects of the covariates on the hazard rate without specifying the distribution of the baseline hazard function (Box-Steffensmeier and Jones 2004). 
Table 1 provides descriptive statistics of the bills used in the subsequent analyses. In total, 1,597 bills are analyzed, of which Congress approved 529. The mean survival time of the approved bills is 640 days (or 21 months), which is considerably shorter than the mean survival time of rejected bills (1285 days or 43 months). The median survival time of the approved bills is 464 days. Figure 1 shows the Kaplan-Meier estimates of survivor functions for approved bills, rejected bills, and all bills. It indicates that most approved bills are decided relatively 'quickly' (given the Brazilian norm); approximately 80 percent of the approved bills were passed within the first 1,000 days. In contrast, decisions to reject involve a rather prolonged process: less than half of the rejected bills had their deliberations concluded within 1,000 days of their initial introduction. However, some of the approved bills also suffer protracted deliberations in Congress as well, with 4.5 percent of approved bills passing Congress after more than 2,000 days of their journey in the institution. These data demonstrate that there is a significant variation in the timing of passage.

Table 1. Life-Span and Outcomes of Bills in the Brazilian Congress, 1995-2004 (in days)

\begin{tabular}{lccccc}
\hline & No of Bills & Mean & Median & Min & Max \\
\hline Approved & 529 & 640 & 464 & 7 & 2,845 \\
\hline Rejected & 165 & 1,285 & 1,124 & 41 & 3,052 \\
\hline All Bills* & 1,597 & 1,269 & 1,104 & 7 & 3,481 \\
\hline
\end{tabular}

${ }^{\star}$ The figures include censored and non-censored cases.

Figure 1. Kaplan-Meier Survival Estimates of Bills in the Brazilian Congress, 1995-2004
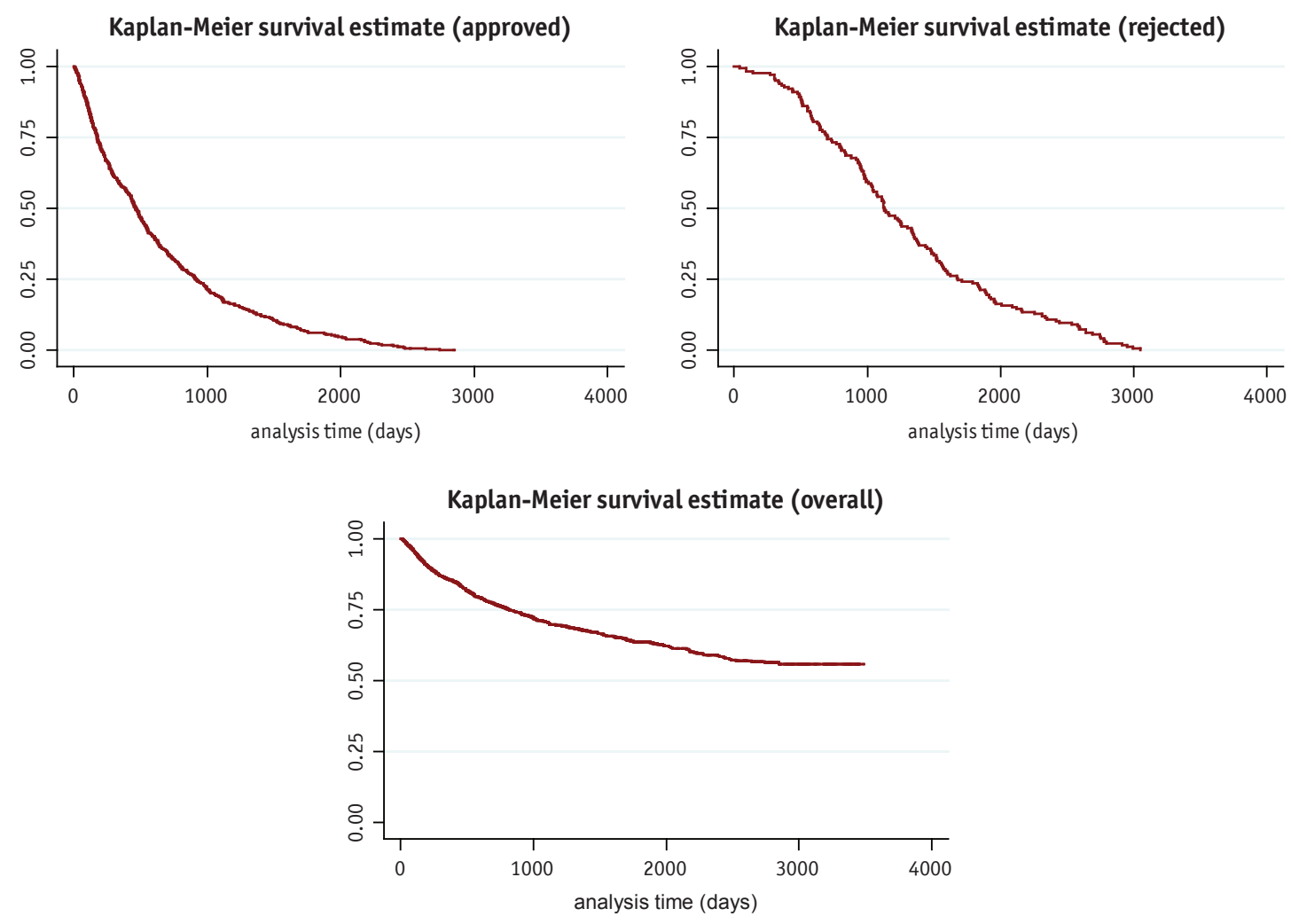

\section{Independent Variables}

Our hypotheses require independent variables measuring various dimensions of conflict. ${ }^{3}$ First, to test the impact of the degree of preference heterogeneity of the members of Congress, we created a variable Preference heterogeneity based on monthly W-Nominate scores of Brazilian deputies. Since our data span over three legislative periods, we use W-Nominate scores in which the median of the Workers Party (Partido dos Trabalhadores) is fixed at -1 and the median of the Liberal Front Party (Partido da Frente Liberal, currently Democratas) at $1 .{ }^{4}$ Preference heterogeneity is the spread between the minimum and maximum W-Nominate scores in each month. ${ }^{5}$

To gauge the impact of the government-opposition divide in Congress, we calculated the size of the governing coalition, Government legislative strength, based on Amorim Neto's (2010) data on cabinet composition using Cebrap's legislative data (2011). Since our hypotheses posit non-linear, $\mathrm{U}$ - and re- 
verse- $U$ curve relationships between the size of the governing forces and the likelihood of bill approval and rejection, respectively, we also enter a quadratic term of this variable in the regression analysis.

We operationalize institutional variables as follows. Bicameral incongruence is measured by the differences in seat shares of the governing coalition between the lower and upper houses.

We measure the impact of voting rules with a dummy variable for Supermajority and another for Absolute majority. In the Brazilian Congress, the supermajority rule (three-fifths majority) is used to examine constitutional amendments and an absolute majority is required for the passage of complementary laws. The reference category is Simple majority used to deliberate on ordinary law bills.

To account for the impact caused by the institutional differences in bills' origins, we include two variables, Executive proposal and Judiciary proposal, with Congressional proposal as the baseline category.

We lagged preference heterogeneity, government legislative strength, and bicameral incongruence by one period to minimize endogeneity problems.

Control variables. We control for contextual variables and proposals' specific features. Honeymoon is the president's "honeymoon" period. It is a dummy variable where 1 represents the first three months of each presidential administration, and 0 otherwise. Election is coded as 1 for four months leading up to concurrent presidential and legislative elections, and 0 otherwise. Both data come from Pereira, Power and Rennó (2005). Finally, we take into consideration various issue-areas in which bills are proposed. In the following regression analysis, we include these issue-areas (administrative, codes and rights, economic, tribute (homenagem), budget, and political-institutional), having social policy as the reference category.

\section{Estimation Results}

We estimated three Cox regressions. Model 1 examines the time in Congress until approval or rejection. In this model, the event of interest is rejection or approval. Model 2 examines duration in Congress until the proposal's final passage, while Model 3 assesses time until rejection. Therefore, by differentiating between approval and rejection, in Models 2 and 3 we analyze different outcomes as competing risks (Box-Steffensmeier and Jones 2004). ${ }^{6}$ Variables that have non-proportional effects based on the analysis of Schoenfeld residuals are interacted with the natural logarithm of time. The results of Models 1 and 2 are similar, so we concentrate on discussing findings from Models 2 and 3.

Table 2. Event History Analysis of Legislative Approval in the Brazilian Congress, 1995-2004

\begin{tabular}{|c|c|c|}
\hline & Model 1 Approval/Rejection & Model 2 Approval \\
\hline \multicolumn{3}{|c|}{ Partisan and Individual Dimensions } \\
\hline Preference heterogeneity & $-0.057(0.424)$ & $0.355(0.474)$ \\
\hline Gov. Legislative Strength & $-0.123^{* *}(0.063)$ & $-0.195 * * *(0.070)$ \\
\hline Gov. Legislative Strength ${ }^{2}$ & $0.001 *(0.001)$ & $0.002 * * *(0.001)$ \\
\hline \multicolumn{3}{|l|}{ Institutional Dimensions } \\
\hline Bicameral incongruence & $31.655^{* * * *}(5.831)$ & $39.241 * * * *(6.684)$ \\
\hline Bicameral incongruence* $\ln (\mathrm{t})$ & $-4.955^{* * * *}(0.856)$ & $-6.359 * * * *(1.044)$ \\
\hline Executive proposal & $8.408^{* * * *}(0.868)$ & $8.194^{* * * *}(0.948)$ \\
\hline Executive proposal* $\ln (\mathrm{t})$ & $-1.222^{* * * *}(0.139)$ & $-1.143^{* * * *}(0.144)$ \\
\hline Judicial proposal & $1.752 * * * *(0.205)$ & $2.120 * * * *(0.203)$ \\
\hline Supermajority & $-0.084(0.161)$ & $-4.233^{* * * *}(0.915)$ \\
\hline Supermajority* $\ln (t)$ & -- & $0.703^{* * * *}(0.144)$ \\
\hline Absolute majority & $0.264(0.196)$ & $0.280(0.211)$ \\
\hline \multicolumn{3}{|l|}{ Control variables } \\
\hline Honeymoon & $-2.073^{* * *}(0.452)$ & $-2.028^{* * * *}(0.507)$ \\
\hline Election & $-0.705(0.190)$ & $-0.801 * * * *(0.225)$ \\
\hline Provisional legislation & $1.188^{* * * *}(0.244)$ & $1.319 * * * *(0.257)$ \\
\hline
\end{tabular}




\begin{tabular}{lcc}
\hline & Model 1 Approval/Rejection & Model 2 Approval \\
\hline Administrative & $0.007(0.114)$ & $0.044(0.130)$ \\
\hline Codes \& Rights & $-0.468^{* * * *}(0.114)$ & $-0.513^{* * *}(0.167)$ \\
\hline Economic & $-0.121(0.119)$ & $-0.112(0.142)$ \\
\hline Tribute & $0.681^{* * * *}(0.138)$ & $0.966^{* * * *}(0.149)$ \\
\hline Budget & $0.624^{* *}(0.263)$ & $0.650^{* *}(0.301)$ \\
\hline Political-institutional & $-0.151(0.222)$ & $-0.248(0.272)$ \\
\hline N & 66,134 & 66,134 \\
\hline Wald Chi-Square & 439.44 & 488.15 \\
\hline
\end{tabular}

Note: Cox regression with the Efron method for ties. Entries are coefficients. Robust standard errors clustered on individual bills are in parentheses. ${ }^{*}$ denotes $p<.10,{ }^{* *} p<.05,{ }^{* *} p<.01$, and ${ }^{* * * *} p<.001$, two-tailed tests.

Table 3. Event History Analysis of Legislative Rejection in the Brazilian Congress, 1995-2004

\begin{tabular}{|c|c|}
\hline & Model 3 Rejection \\
\hline \multicolumn{2}{|c|}{ Partisan and Individual Dimensions } \\
\hline Preference heterogeneity & $-4.189 * * * *(0.885)$ \\
\hline Gov. Legislative Strength & $0.434 * * *(0.155)$ \\
\hline Gov. Legislative Strength ${ }^{2}$ & $-0.004 * * *(0.001)$ \\
\hline \multicolumn{2}{|l|}{ Institutional Dimensions } \\
\hline Bicameral incongruence & $-4.644 * *(2.192)$ \\
\hline Executive proposal & $6.833^{* *}(2.758)$ \\
\hline Executive proposal ${ }^{*} \ln (\mathrm{t})$ & $-1.188 * * *(0.443)$ \\
\hline Supermajority & $-0.327(0.426)$ \\
\hline Absolute majority & $0.102(0.462)$ \\
\hline \multicolumn{2}{|l|}{ Control variables } \\
\hline Honeymoon & $-2.439 * *(1.002)$ \\
\hline Election & $-0.217(0.364)$ \\
\hline Administrative & $-0.263(0.242)$ \\
\hline Codes \& Rights & $-0.379(0.235)$ \\
\hline Economic & $-0.096(0.222)$ \\
\hline Tribute & $-0.575(0.409)$ \\
\hline Budget & $0.810(0.557)$ \\
\hline Political-institutional & $-0.082(0.374)$ \\
\hline $\mathrm{N}$ & 66,134 \\
\hline Wald Chi-Square & 58.87 \\
\hline
\end{tabular}

Note: Cox regression with the Efron method for ties. Entries are coefficients. Robust standard errors clustered on individual bills are in parentheses. ${ }^{*}$ denotes $p<.10,{ }^{* *} p<.05,{ }^{* *} p<.01$, and ${ }^{* * *} p<.001$, two-tailed tests.

Overall, the results strongly support most of the hypotheses, with statistically significant coefficients. The results also reveal interesting variations in the effects of various dimensions of conflict.

First, as predicted, we find that the asymmetric distribution of seats between the governing coalition and opposition increases the likelihood of bill approval while it is less likely when the government and opposition forces are more evenly distributed. Likewise, legislative rejection is less likely when the size of the governing coalition is either very small or very large, but rejection becomes more likely when the government and opposition forces are near parity. These findings are supported by a significant negative (positive) coefficient for government legislative strength, and a significant positive (negative) coefficient for the variable's squared term, indicating a U-shaped (reverse U-shaped) relationship between the size of the governing coalition and bill approval (rejection).

However, according to our calculation, the turning point in the relationship between coalition size and 
bill approval or rejection is not precisely at the point that divides the government and opposition forces evenly. Rather, the lowest likelihood of bill approval is indicated where the government seat share is about 65 percent, and the highest likelihood of rejection is found where coalition size is about 60 percent. In other words, these turning points are found not at the size of the minimum winning coalition but at a slightly oversized coalition. This finding probably reflects the reality of Brazilian legislative politics, and can be interpreted in two ways. First, given many defections in voting on controversial bills, a slightly oversized governing coalition is practically at parity with the forces of opposition. Second, during the period examined in this analysis, many major government initiatives were presented in the form of constitutional amendments. The estimated turning point approximates a 60 percent majority required for the approval of constitutional amendment proposals.

In any case, these findings provide support for our claim: when government and opposition forces are at par, the legislative game turns into zero sum, engendering bargaining difficulty and inducing mutual vetoes of their proposals. These results also suggest that the government-opposition distinction does have a useful meaning even where many parties are known to be weak and individual members, and also parties, switch their affiliations.

Nevertheless, this does not mean that all that matters in Brazil is the government-opposition distinction. In fact, the distribution of the preferences of individual legislators also affects the legislative process. Even though it does not have a statistically significant influence on bill approval, its negative coefficient in Table 3 shows that it delays decisions with respect to rejection. That is, when consensus building is difficult due to individual preference heterogeneity, there is a tendency to postpone decisions rather than quickly rejecting the proposal.

Our analysis also indicates that institutional variables exert important influences on lawmaking. We find that the effects of bicameral incongruence vary over time. The variable initially has positive effects on approval as its positive coefficient indicates, but the negative sign of the coefficient for the time interaction suggests decay in the original effect over time, eventually turning negative. The point in time at which an effect flips from positive to negative (and vice versa) can be obtained by exponentiating the ratio of the constituent coefficient to the interaction coefficient, $\exp \left(\left|\beta^{c}\right| /\left|\beta^{i}\right|\right)$ (Box-Steffensmeier and Zorn 1998; Licht 2011). By our calculation, the effect of bicameral incongruence turns negative on the $478^{\text {th }}$ day after a bill is introduced in the Congress. Therefore, even though the initial effect of bicameral incongruence is positive, since the mean survival time in Congress for bill approval is 640 days, its approval delaying effect is more important. On the other hand, bicameral incongruence has a delaying effect on legislative rejection. Thus, at least during this period under investigation, the general effect of bicameral incongruence is to slow down the decision-making processes.

Executive proposals and judicial proposal are also more likely to be approved faster than congressional proposals. Interestingly, executive proposals also tend to be rejected more quickly than congressional proposals. Moreover, our analysis also shows that the effects of executive proposals are time-variant, showing a decay in the executive advantage over time. Also, during the period under investigation, the negative effect of executive proposals commences on the $1,298^{\text {th }}$ day for the approval model, but given the mean approval time, this negative effect could be minor. The effects of executive proposal switch on the $314^{\text {th }}$ day in the rejection model. Since the mean rejection time is 1,285 days, even though some executive proposals may be rejected by Congress quickly, the delaying effect is much more substantial.

Finally, voting rules yielded mixed results. We examined both absolute majority and three-fifths majority rules; only the three-fifths majority rule has a significant, time-varying effect, and only in the approval model. The three-fifths supermajority rule lowers the likelihood of a bill's approval compared to the simple majority rule initially, as expected, but as time passes, its effects turn positive.

\section{Conclusion}

Brazil has a presidential bicameral system embodying separation of powers in its constitution. In this way, it is very similar to the United States and most other Latin American countries. However, Latin America differs from the United States in the structure of its party systems, electoral rules, and the distribution of legislative prerogatives. The region is marked by multiparty systems that engender a potentially distinct form of governing and new challenges to how majorities are constructed in the legislative arena. In many countries, parties are not only in abundant supply; many are formed and disbanded in relatively short periods of time.

The obvious question, which spurs the discussion and analysis presented in this paper, is: Are the theories based on government-opposition rivalries relevant in places where multiple parties exist and party discipline cannot be taken for granted? Or are explanations stressing individual legislators and their preferences more relevant in such systems?

In the classic case of the U.S. presidential system, the theory of divided government has achieved a privileged status as a major reference point in analyzing lawmaking. However, in multiparty presidential systems with weak and inchoate parties, the division between government and opposition is not so clear-cut. Rather than examining the inter-branch conflict directly, we thus turned our at- 
tention to forces within the legislature and asked the essential question that underlies the theory of divided government: government-opposition rivalry. We argued that government-opposition rivalry intensifies when both sides are roughly equal in legislative strength. Under such conditions, we expect bargaining difficulties and mutual vetoes of the other party's proposals, delaying proposal approval and increasing the likelihood of bill rejection.

This initial motivation stimulated the investigation about how various individual, partisan, and institutional factors influence lawmaking in Brazil, a case of coalitional presidentialism. Prior research on gridlock has also emphasized institutional causes of legislative stalemate, such as bicameral differences and supermajority rules. Is bicameral conflict pertinent in a system where executives tend to dominate legislative processes? Do supermajority rules generate a greater propensity for gridlock even in places where presidents are armed with many legislative prerogatives not available to U.S. presidents?
We found support for most of the hypotheses in the event history analysis of legislative proposals considered by the Brazilian Congress. The government-opposition divide has important effects on both bill approval and rejection, and so does the distribution of the preferences of individual legislators. We also found that institutional dimensions of conflict, such as bicameral differences and executive initiatives, influence both durations and outcomes of lawmaking in Brazil.

This paper therefore contributes to our understanding of inter-coalition, inter-branch, and inter-cameral politics. However, this paper did not address the question of coordination within coalitions. How do politics within coalitions affect policymaking processes? In multiparty coalitional systems, managing coalitions is an important task to ensure governability for the president, or effective opposition for the parties in opposition. There is certainly more work to do to better understand legislative processes and outcomes.

\section{Bibliography}

ALMEIDA, Acir and SANTOS, Fabiano. 2008. "Asymmetric Information and Legislative Process: The Politics of Presidential Decrees in Brazil." Unpublished manuscript.

ALSTON, Lee J.; MUELLER, Bernardo. 2005. "Pork for Policy: Executive and Legislative Exchange in Brazil." The Journal of Law, Economics, \& Organization, 22:1, 87-114.

AMORIM NETO, Octavio. 2010. “El Moderno Sistema Govierno Presidencial Brasileño." Unpublished manuscript.

AMORIM NETO, Octávio and Paulo Tafner. 2002. "Governos de coalizão e mecanismos de alarme de incêndio no controle legislativo das medidas provisórias." Dados 45, 5-58.

AMORIM NETO, Octavio, Gary W. Cox, and Mathew D. McCubbins. 2003. "Agenda Power in Brazil's Câmara dos Deputados, 1989-98." World Politics, 55, 550-78.

AMES, Barry. 2001. The Deadlock of Democracy in Brazil. Ann Arbor: The University of Michigan Press.

BINDER, Sarah A. 1999. “The Dynamics of Legislative Gridlock, 1947-96.” American Political Science Review, 93:3, 519-533.

BINDER, Sarah A. 2003. Stalemate: Causes and Consequences of Legislative Gridlock. Washington, D.C.: Brookings Institution Press.

BOTERO, Felipe and RENNO, Lucio. 2007. “Career Choice and Legislative Reelection: Evidence from Brazil and Colombia." Brazilian Political Science Review 1, 102-124.

BOX-STEFFENSMEIER, Janet M., and BRADFORD S. Jones. 2004. Event History Modeling: A Guide for Social Scientists. New York: Cambridge University Press.

CHEIBUB, José Antonio, Adam Przeworski, and Sebastian M. Saiegh. 2004. “Government Coalitions and Legislative Success Under Presidentialism and Parliamentarism." British Journal of Political Science 34, 565-587.

CLOSE, David, ed. 1994. Legislatures and the New Democracies in Latin America. Boulder, London: Lynne Rienner Pub.

COX, Gary W. and MORGENSTERN, Scott. 2001. “Epilogue: Latin America's Reactive Assemblies and Proactive Presidents." In: Legislative Politics in Latin America, Scott Morgenstern and Benito Nacif eds. Cambridge: Cambridge University Press.

CRISP, Brian e DESPOSATO, Scott. 2004. "Constituency Building in Multimember Districts: Collusion or Conflict?" The Journal of Politics, 66:1, 136-156.

FIGUEIRED0, Argelina, and Fernando Limongi. 1999. Executivo e Legislativo na Nova Ordem Constitucional. Rio de Janeiro: Editora Fundação Getulio Vargas.

FIORINA, Morris. 1996. Divided Government. Second Edition. Needham Heights, MA: Allyn and Bacon.

HALLERBERG, Mark, Carlos Scartascini, and Ernesto Stein. 2009. Who Decides the Budget? A Political Economy Analysis of the Budget Process in Latin America, Cambridge: Harvard University Press.

HIROI, Taeko. 2008. "The Dynamics of Lawmaking in a Bicameral Legislature: The Case of Brazil." Comparative Political Studies 41:12, 1583-1606.

JOHNSON, Gregg and CRISP, Brian. 2003. "Mandates, Powers, and Policies." American Journal of Political Science 47:1, 128-142.

KREHBIEL, Keith. 1996. "Institutional and Partisan Sources of Gridlock: A Theory of Divided and Unified Government." Journal of Theoretical Politics 8:1, 7-40. 
KREHBIEL, Keith. 1998. Pivotal Politics: A Theory of U.S. Lawmaking. Chicago and London: The University of Chicago Press.

LLANOS, Mariana and MAINSTENTREDET, Leiv, eds. 2010. Presidential Breakdowns in Latin America: Causes and Outcomes of Executive Instability in Developing Democracies, Palgrave, New York.

LAVER, Michael, and KENNETH A. Shepsle. 1991. “Divided Government: America is Not 'Exceptional.' Governance 4:3, 250-269.

LICHT, Amanda. 2011. "Change Comes with Time: Interpreting the Substantive Impact of Non-Proportional Hazards in Event History Analysis." Political Analysis 19:2, 227-243.

LINZ, Juan J. 1978. The breakdown of democratic regimes: crisis, breakdown, and reequilibration. Baltimore, London: Johns Hopkins University Press

MAINWARING, Scott. 1999. Rethinking Party Systems in the Third Wave: The Case of Brazil. Stanford: Stanford University Press.

MAINWARING, Scott P. and SCULLY, Timothy, eds. 1995. Building Democratic Institutions: Party Systems in Latin America. Stanford: Stanford University Press.

MALTZMAN, F. and SHIPAN, C. 2008. "Change, Continuity and the Evolution of Law." American Political Science Review. 52:2, 252-67.

MAYHEW, David R. 1991. Divided We Govern: Party Control, Lawmaking, and Investigations, 1946-1990. New Haven and London: Yale University Press.

NEGRETTO, Gabriel L. 2004. "Policy Making by Decree in Latin America: The Cases of Brazil and Argentina." Comparative Political Studies, 37:5, pp. 531-562.

PACHÓN, Monica. 2008. Cross-avenue politics: the case of Colombia and Brazil. Ph.D. Thesis, University of California, San Diego.

PALANZA, Valeria. 2009. "Lawmaking In Brazil: Decrees vs. Statutes", Paper Presented at the Latin American Studies Association Meeting, Rio de Janeiro, Brazil.

PEREIRA, Carlos, Timothy J. Power, and Lucio Rennó. 2005. “Under What Conditions Do Presidents Resort to Decree Power? Theory and Evidence from the Brazilian Case." Journal of Politics, 67:1, 178-200.

PEREZ-LIÑAN, Anibal. 2007. Presidential Impeachment and the New Political Instability in Latin America. Cambridge, Cambridge University Press.

POWER, Timothy J. 1998. "The Pen is Mightier than the Congress: Presidential Decree Authority in Brazil." In John Carey and Matthew Soberg Shugart, eds., Executive Decree Authority: Calling Out the Tanks or Filling Out the Forms? New York: Cambridge University Press.

REICH, Gary. 2002. “Executive Decree Authority in Brazil: How Reactive Legislators Influence Policy." Legislative Studies Quarterly, 27, 5-31.

ROGERS, James R. 1998. "Bicameral Sequence: Theory and State Legislative Evidence." American Journal of Political Science, 42:4, 1025-1060.

SANTOS, W. G. 1986. Sessenta e Quatro: Anatomia da Crise. São Paulo: Vértice.

SHUGART, Matthew Soberg, and John M. Carey. 1992. Presidents and Assemblies: Constitutional Design and Electoral Dynamics. Cambridge and New York: Cambridge University Press.

Tsebelis, George, and Jeannette Money. 1997. Bicameralism. Cambridge and New York: Cambridge University Press.

TSEBELIS, George e ALEMAN, Eduardo. 2005. "Presidential Conditional Agenda Setting in Latin America”. World Politics - Volume 57, Number 3, pp. 396-420.

\section{Notas}

1 This selection method considers only those bills that cleared the hurdle of approval at least in the legislative body of origin, be it the Executive, Judiciary, Senate, or Chamber of Deputies. At the same time, it helps remove the bills that were proposed simply for the sake of proposing (which many members of Congress do). See Hiroi (2008) for detailed information on the dataset and selection procedure.

2 In Brazil, many bills stay in Congress over multiple legislative periods.

3 Unless otherwise stated, we use variables in the legislative dataset compiled by Hiroi (2008).

4 We thank Eduardo Leoni for suggesting this and supplying the W-Nominate data.

5 Ideally we would include W-Nominate scores for the senators as well. Unfortunately, these data are not available during this period under examination.

6 In this approach, outcomes other than approval are treated as censored in the approval model, and outcomes other than rejection are treated as censored in the rejection model. 